International Journal of Linguistics, Literature and Culture
Available online at https://sloap.org/journals/index.php/ijllc/
Vol. 7, No. 3, May 2021, pages: 120-129
ISSN: 2455-8028
https://doi.org/10.21744/ijllc.v7n3.1476

\title{
Resistance and Counter Hegemony of Ma'ya Tribe to Bureaucratic Hegemony Practices in Raja Ampat, West Papua
}

\author{
George Mentansan a \\ Phil I Ketut Ardhana ${ }^{b}$ \\ I Nyoman Suarka ${ }^{c}$ \\ I Nyoman Dhana ${ }^{\mathrm{d}}$
}

\section{Article history:}

Submitted: 27 February 2021

Revised: 9 March 2021

Accepted: 12 April 2021

\section{Keywords:}

counter hegemony;

hegemony;

ma'ya;

raja ampat;

resistance;

\begin{abstract}
The establishment of a regional marine conservation area in Raja Ampat is a hegemonic practice carried out by the Raja Ampat bureaucracy with conservation NGOs, such as TNC and CI which has reaped various responses. Some people accept the presence of conservation areas and those who do not. Therefore, this study aims to reveal the resistance and counterhegemony responses of the Ma'ya tribe in the conservation area to the practice of bureaucratic hegemony in Raja Ampat, West Papua. The research was conducted using a qualitative descriptive method. Data collection by observation, in-depth interviews, FGD and documentation, and the results of the research are presented in a descriptive narrative. The results of the study show that the resistance of the Ma'ya tribe in Raja Ampat to bureaucratic hegemony in the conservation area is through blocking and taking over the monitoring post of the conservation area; prosecution of customary land rights, and reluctance to involve themselves in conservation activities. Counter-hegemony practices are carried out through the formation of customary fishing areas and the struggle for the establishment of regional regulations regarding the rights of indigenous Ma'ya tribes.
\end{abstract}

International journal of linguistics, literature and culture (c) 2021. This is an open access article under the CC BY-NC-ND license (https://creativecommons.org/licenses/by-nc-nd/4.0/).

Corresponding author:

Mentansan, G.

Universitas Papua Manokwari, Papua Barat, Indonesia

Email address: georgementansan@gmail.com

\footnotetext{
${ }^{a}$ Universitas Papua Manokwari, Papua Barat, Indonesia

${ }^{\mathrm{b}}$ Doctoral Program of Cultural Studies, Faculty of Humanities, Universitas Udayana, Denpasar, Indonesia

${ }^{c}$ Doctoral Program of Cultural Studies, Faculty of Humanities, Universitas Udayana, Denpasar, Indonesia

${ }^{\mathrm{d}}$ Doctoral Program of Cultural Studies, Faculty of Humanities, Universitas Udayana, Denpasar, Indonesia
} 


\section{Introduction}

Raja Ampat has an area of water that reaches 80 percent and only 20 percent of the land. This condition makes the Raja Ampat region said to be an archipelagic district located in the bird's head landscape of West Papua Province. The area of the waters that are dominant and their strategic location because they are in the world's coral triangle, namely: the Philippines, Indonesia and Papua New Guinea (Maria et al., 2007; Hedley et al., 2013; Divya et al., 2010) make these waters contain a richness of tropical biodiversity is high (Bonnke et al., 2017; Anna et al., 2014; Irawan et al., 2018).

Tropical biodiversity in the waters of Raja Ampat does not escape the threat of degradation and damage caused by the use of destructive fishing gear and overfishing patterns (Augustina et al., 2015, Widayatun, 2016). This fact is done by fishermen from outside Raja Ampat who practices destructive modern fishing technology. It is made worse by the support of local fishermen who adopt the use of destructive fishing gear and also use them massively, such as the use of bombs and cyanide. Based on various studies conducted by international and national scientists, Raja Ampat waters must be immediately saved by implementing the right strategy to eliminate the potential and threat of damage while protecting and conserving tropical biodiversity in Raja Ampat. Therefore, the strategy to save and protect biodiversity in this area is carried out through the establishment of the Raja Ampat marine conservation area. The initiative to establish a conservation area has also been driven by international NGOs, such as TNC (The Nature Conservancy) and CI (Conservation International). Through hard work and fast work as well as the involvement of all levels of society and the bureaucracy, conservation NGOs guerrilla for outreach, seminars, focus group discussions, meetings held from village to village to obtain approval and commitment from the Ma'ya tribe as land and sea leaders so that it can be used as an area for the establishment of a conservation area. As a result of the hard work of conservation NGOs and the Raja Ampat bureaucracy, support from the indigenous Ma'ya tribe gave up their marine Petuanan rights to be used as marine conservation areas. The agreement and commitment of the indigenous Ma'ya tribes in the establishment of a conservation area were carried out through a customary declaration on 15 November 2006 in Waifoi village, Teluk Mayalibit District, Waigeo Island to hand over the customary mandate to the Raja Ampat bureaucracy to designate Ma'ya customary Petuanan (landlord) areas into conservation areas regional sea (Kawasan Konservasi Laut Daerah/KKLD).

The Regent of Raja Ampat followed up with a positive response in determining the area's marine conservation areas into 5 areas consisting of: the marine conservation area of Mayalibit Bay, Kawe, Dampier Strait, Kofiau-Boo Islands, and East-South Misool. These areas have been stipulated in the Raja Ampat District Regulation Number 27 of 2008. At present, the age of the conservation area in the indigenous Ma'ya waters in Raja Ampat has been 15 years and has had a significant impact on the protection and protection of the Ma'ya community utilization of aquatic natural resources for the benefit of the community and the bureaucracy, such as developing fisheries and tourism. However, in the development and changes of the Ma'ya community regarding the benefits of the Raja Ampat marine conservation area, it turns out to also have a detrimental impact on the Ma'ya tribe who are based on long experiences and reflections by the Ma'ya community, such as control and use of natural resources. Tourism potential is controlled by foreign entrepreneurs and people from outside Raja Ampat, while the Ma'ya tribe does not have the opportunity to manage their natural marine resources for tourism purposes. The policy direction and development orientation are prioritized for the protection and preservation of marine natural resources, but the human resources of the Ma'ya tribe are neglected and even marginalized in all aspects of life. This condition caused various reactions and actions to generate resistance and counter-hegemony responses to the Raja Ampat bureaucracy in managing marine conservation areas in the Raja Ampat area.

\section{Materials and Methods}

Based on the object of research, research can be classified into critical studies to understand the various complex ways used by power to dominate and shape consciousness. Power, based on the experience of critical theorists, is an ambiguous topic that demands detailed and in-depth study and analysis. Power is "a basic element of human existence that functions to form the hallmark of human tradition that is both oppressive and productive" (Denzin $\boldsymbol{\&}$ Lincoln, 2011; Peters \& Reid, 2009; Nepomuceno et al., 2019). This study used a descriptive qualitative method with a cultural studies approach. The qualitative method is used because the researcher is used as a key instrument and the data collection technique is carried out by combining and analyzing inductive data (Sugiyono, 2015). Field data collection was carried out by observation, in-depth interviews, FGD, and documentation. The research data were

Mentansan, G., Ardhana, P. I. K., Suarka, I. N., \& Dhana, I. N. (2021). Resistance and counter hegemony of Ma'ya tribe to bureaucratic hegemony practices in Raja Ampat, West Papua. International Journal of Linguistics, 
analyzed by referring to the analysis model of Miles and Huberman (Sugiyono, 2015), namely: data reduction, data presentation, and concluding. The results of the data analysis are presented in a descriptive narrative equipped with photos and pictures to answer the research objectives regarding the resistance and counter-hegemony of the Ma'ya tribe in the conservation area against the practice of bureaucratic hegemony in Raja Ampat, West Papua Province.

\section{Results and Discussions}

\subsection{Resistance of the Ma'ya to the Hegemony of the Raja Ampat Bureaucracy}

The practice of hegemony is not always lasting and permanent because when hegemony reaches its climax, there is a great chance and risk of collapse and destruction. This situation also occurred in how the bureaucratic hegemony of the Ma'ya tribe in Raja Ampat was carried out, moved, and reached its peak with the customs declaration for the establishment of a marine conservation area in the Mayalibit Bay of Raja Ampat. But in the end, the hegemonic movement that was established for 15 years finally experienced an anti-climax that gave birth to resistance and counter-hegemony as a negative reaction to inhuman hegemonic actions, cutting and freezing their space like a robot controlled and moved at will, the hegemony class against the Ma tribe community. 'Yes. The theories underlying historically state that in history there were periods when social classes became separated from their political parties, the situation became dangerous because violent solutions could have been used, and the traditional meaning of the state was used as a means of maintaining the hegemony of the dominant class. It will get worse" (Patria \& Arief, 2003). Likewise with the character of hegemony which is full of power, where there is power there emerges resistance to it. The social relations of civil society have given rise to not only class struggle, but also various social movements involved in the struggle for democracy-people who do not have class character but are visible on the surface of the Ma'ya tribe through physical movements of resistance. These struggles influenced the character and form of state institutions and civil society organizations, resulting in that these struggles were not merely instruments of the ruling class, but reflected the balance of power in civil society (Simon, 2004). This reaction arose among the Ma'ya tribe on the reflection of the benefits and self-emotions arising from conservation practices that were more monopolized by conservation NGOs TNC and CI in their management. Therefore, to form a rival class that can facilitate and organize the aspirations and expressions of the Ma'ya, the working class must dismantle the system of fortifications and defenses that support bourgeois hegemony by building alliances with all social movements that are trying to change relations in society. civil. Referring to field research, it turns out that the Ma'ya tribe in Raja Ampat is starting to show the seeds of resistance and thorns in the flesh for hegemonic, namely conservation NGOs and the Raja Ampat Bureaucracy as a threat to the actions of the Raja Ampat bureaucratic hegemony. Resistance movements began to grow and show their form at the level of social life in the Ma'yalibit Bay. Rejection has started to emerge in the villages, there have been actions of blocking and taking over of conservation area monitoring posts in an increasingly sporadic form by the owners of customary land rights, violations of the zoning of conservation areas that have been established increasingly by individuals in the Ma'ya tribal village in Teluk Ma'yalibit as well as the formation of alliances in the name of the indigenous and tribal Ma'ya.

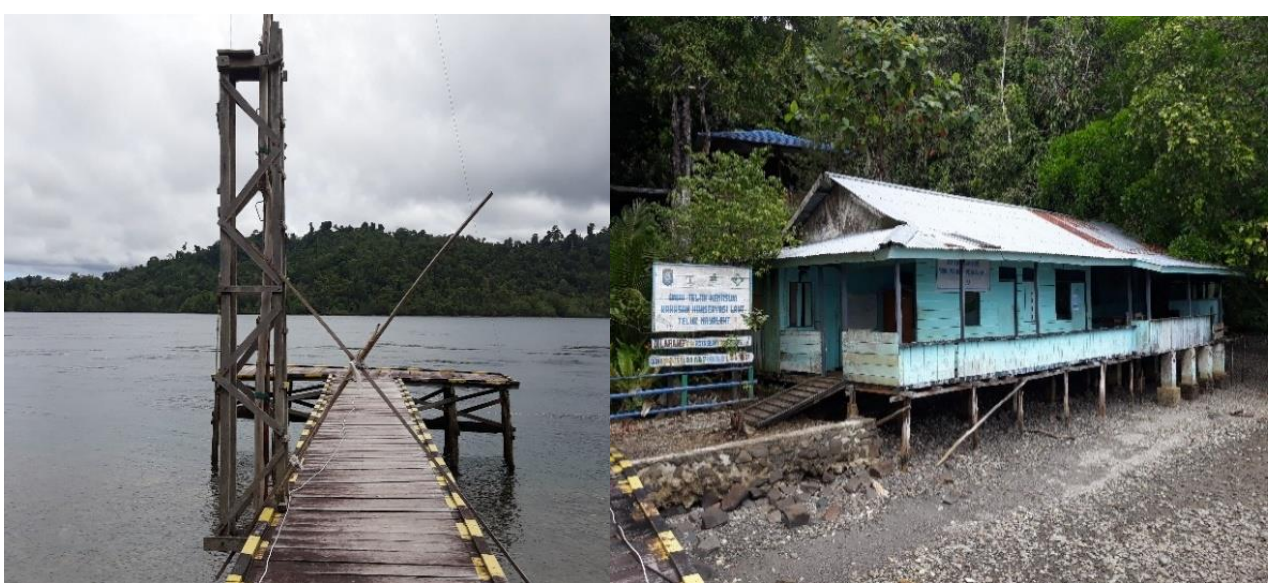

Figure 1. Actions of blocking and closing of conservation area monitoring posts 
The act of blocking the conservation area monitoring post in Ma'yalibit Bay was carried out by unscrupulous customary rights owners in the Mayalibit Bay of Raja Ampat because they felt disappointed and there was no involvement of customary owners in the management and supervision of the conservation area. Besides, the blocking of conservation area monitoring posts is an accumulation of the view that the presence of conservation areas does not have an economic impact on increasing income as fishermen. On the other hand, the Ma'ya fishermen are limited and regulated about the fishing area, fishing gear, and types of fish that can be caught. This condition causes a decrease in the catch of fishermen which has an impact on their income. On the other hand, the beneficial impacts appear to be high for the leader of the conservation area sites in Raja Ampat because they receive large operational costs to control and supervise conservation areas. The hegemonic power exercised by the bourgeoisie through organizations in civil society must continue to be weakened by the counter-power of social movements originating from the activities of members of the united movements under the leadership of the working class. This position war does not exclude the possibility of violent resistance against the coercive organs of the state. Terms such as' crisis of authority, 'crisis of hegemony', 'war of positions',' revolutionary movement ',' national-popular ', and intellectual and moral reform 'are used to characterize an adult movement behind civil society struggles or counter-hegemony over acts of populist hegemony over it.

Based on Gramsci's theory above, the reaction of the Ma'ya tribe to the hegemony carried out by the Raja Ampat bureaucracy also resulted in a resistance response. Resistance and counter-hegemony carried out by the Raja Ampat bureaucratic hegemony against the Ma'ya tribe in Ma'yalibit Bay as one of the conservation areas of 5 regional marine conservation areas (KKPD) in Raja Ampat, West Papua Province. Resistance or resistance carried out by the Ma'ya tribe in the Ma'yalibit Bay conservation area was directed at conservation NGOs, especially Conservation International who work in Raja Ampat and the Raja Ampat bureaucracy. The aspect of the modern crisis which is complained of as a materialist wave is related to the crisis of authority. This authority crisis occurs when the ruling class has lost its consensus, for example no longer leading but only dominant, using its own coercive forces, this means that the masses in large numbers have been released from their traditional ideology and no longer believe what they previously believed. The crisis is precisely contained in the fact that "something old is dying and something new cannot be born" (Gramsci, 2003). High poverty, the death of old ideologies, neglect of the Ma'ya economy and politics means a reduction from the high superstructure to a level that is tightly attached to the structure itself. Then the possibility and need to create a new culture or counter-hegemony movement is very possible. The counter-hegemony directed at NGOs and the Raja Ampat bureaucracy was because the initiator and composer of the establishment of a conservation area in Raja Ampat was a conservation NGO and worked diligently and shrewdly to garner support and commitment from the Ma'ya tribe to the formation of conservation areas with the lure of preservation, protection of natural resources from damage and destruction; empowerment and improvement of the economy of the Ma'ya tribe as well as the promises that from the beginning of the formation of this area were not kept. The contribution and impact of significant changes from the Raja Ampat marine conservation area have not resulted in maximum changes for the Ma'ya tribe, while other tribes in Raja Ampat have received positive benefits. This condition is seen from the support of the Raja Ampat bureaucracy in empowering and developing community tourism potential independently. Meanwhile, the Ma'ya tribe in Teluk Mayalibit did not receive support from the Raja Ampat bureaucracy as explained by Nikson Ansan in Warsambin village on August 302018 as follows.

"Dong punya isu-isu terlalu banyak. Dong bilang nanti ada bantuan kesini-kesinikesini, bantuan itu ah....ini masyarakat orang kampung ini kalo kitorang bilang dong ingat tapi dong tra tepati. Janji-janji ini yang bikin masyarakat palang tempat-tempat konservasi. Konservasi itu stop sudah...Cuma janji-janji muluk saja. Bicara konservasi tapi masyarakat tidak diperhatikan”.

Translation

Dong has too many issues. Dong said that later there will be helpful here and there, the assistance is ah.... Now the villagers of this village, if we say, remember it but please keep it. These promises are what make people cross conservation areas. Conservation has stopped ... Just grandiose promises. Talking about conservation but the community is not being noticed.

Mentansan, G., Ardhana, P. I. K., Suarka, I. N., \& Dhana, I. N. (2021). Resistance and counter hegemony of Ma'ya tribe to bureaucratic hegemony practices in Raja Ampat, West Papua. International Journal of Linguistics, Literature and Culture, 7(3), 120-129. https://doi.org/10.21744/ijllc.v7n3.1476 
The crisis of trust in hopes and promises did not prove to be an anti-climax of the Ma'ya tribe against the benefits of the conservation area and the Raja Ampat bureaucracy and conservation NGOs. The awakening of awareness of the glorified conservation promises of the existence of a conservation area for those in Ma'yalibit Bay has not been proven, the limitation of fishing areas with a zoning of waters has resulted in rigid and regulated freedom of fishing. On the other hand, the benefits obtained from the establishment of a conservation area are that the availability of fish stocks in the waters of the Ma'ya tribe increases and the safety and health of coral reefs and another marine biota.

\subsection{Counter Hegemony of the Ma'ya Tribe through the Establishment of Customary Fishing Areas}

The hegemony crisis that presents "counter-hegemony and acts of resistance occurs when the mass consciousness is there and is ready to take action this development of consciousness will produce revolutionary changes" (Patria \& Arief, 2003). Referring to the above theory, it is understood that when the awareness of the Ma'ya tribe has been formed which is based on life experiences, the reality and practices of violence and coercive domination by the Raja Ampat bureaucracy will generate and form solidarity and have an impact on tribal revolutionary movements Ma'ya in the Ma'yalibit Bay conservation area. The establishment of customary fishing areas is a tangible form of the Ma'ya tribal counter-hegemony action against the bureaucracy that is headed by the organic intellectuals of the Ma'ya tribe who work in conservation NGOs and hold Ma'ya tribal customary councils (DAS MA'YA). The strategic positions in conservation NGOs and the cultural positions that were obtained gave the Ma'ya intellectuals the flexibility to promote counter-hegemony in the form of initiatives and models of area management in the form of customary fisheries areas. The customary fishery area has taken over the management of the area that was previously under the control of the Raja Ampat bureaucracy, especially the Regional Public Service Agency (Badan Layanan Umum Daerah/BLUD) as a technical implementing unit that manages and oversees marine conservation areas in Raja Ampat. Customary fishery areas are seen as an effort to directly involve and actively participate in the indigenous Ma'ya community in managing, utilizing, and supervising conservation areas so that they have a feeling of belonging and receiving direct benefits from the existence of the area. On the other hand, from a critical perspective it is understood that through this customary fishing area, there has been a coup against the Raja Ampat bureaucracy that has long managed and utilized this area. The coup was meant to completely control conservation areas, thereby weakening and eliminating the authority of the Raja Ampat bureaucracy in intervening and exploiting the natural resource potentials of the Ma'ya tribal waters.

The mobilization and movement of the masses by the organic intellectuals of the Ma'ya tribe in the DAS-MA'YA carriage is a strong foundation and foundation for carrying out the counter-hegemony created by the mass organizations of the working class by building institutions and developing a proletarian culture" (Patria and Arief: 2003) the organic intellectuals of the Ma'ya tribe who from the beginning of the plan to form a conservation area worked continuously and aggressively so that the formation of a conservation area has turned away by designing and establishing customary fishing areas. Maya intellectuals use the media of Ma'ya tribal councils to go fast and overthrow the power of hegemony to become the right strategy for resistance and counter-hegemony that has been happening in the marine conservation area of the Ma'ya tribal community by the Raja Ampat bureaucracy. The purpose of establishing customary fisheries areas in a positive view is that the existence of customary fisheries areas provides the widest possible opportunity for indigenous peoples who are within or around the area to manage, utilize and supervise their customary waters because this area is their landlord area. However, from a critical point of view, the objective of this area is a reaction to the practice of establishing a protected area for local waters, which has provided minimum benefits for indigenous peoples, while conservation NGOs and the Raja Ampat bureaucracy have reaped maximum success from its economic aspect. 


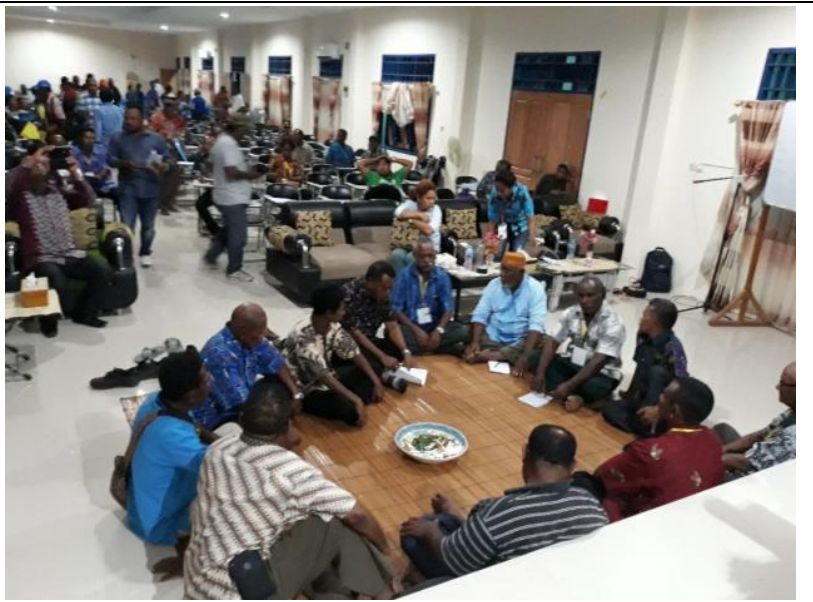

Figure 2. Consolidation of the Ma'ya tribe through customary deliberations in Waisai Raja Ampat

The practice of consolidating the Ma'ya tribe in customary meetings of the Ma'ya tribe in Waisai, Raja Ampat Regency involves most of the Keret heads that are throughout the Raja Ampat islands. This customary deliberation activity is carried out in addition to electing the chairman of the Raja Ampat customary council, the customary deliberation is also a form of activity to close the ranks of culture to form cultural organizations and initiate programs to protect the basic rights of the Ma'ya tribe and empower the Ma'ya people who have biodiversity. Tropical seas are high but low in welfare in Raja Ampat.

Besides, through customary fishing areas, there is pruning and imposition of the power of the regional bureaucracy to control and control the people optimally. The existence of a transition movement towards a new situation, where a situation characterized by the intrinsic instability of the political spaces in it gave birth to the identity of the cultural forces of the Ma'ya tribe who were struggling to shift towards resistance and constantly demand to redefine the social reality of the Ma. 'Yes, regarding conservation areas relentlessly for the Ma'ya tribe (Laclau \& Mouffe, 2008) as said by the Chairman of the customary council of the Ma'ya Kristian Thebu on 18 December 2018 as follows.

"Sudah saatnya masyarakat ambil alih pemanfaatan dan pengelolaan kawasan konservasi ini. Banyak orang yang tra tau konsep perikanan adat maka konsep kawasan perikanan adat ini kitong perjuangkan. Supaya masyarakat dong bisa dapat manfaat langsung tiap-tiap kampung dengan dong yang atur bagaimana mau datangkan nelayan luar untuk tangkap ikan di dong pu hak tapi bayar langsung ke masyarakat atau masyarakat dong atur dong yang tangkap dan jual kepada nelayan luar saja”.

\section{Translation}

"It is time for the community to take over the use and management of this conservation area. Many people are familiar with the concept of customary fisheries, so the concept of this customary fishing area is what we are fighting for. So that the community can get direct benefits from each village by regulating how to bring in outside fishermen to catch fish in dong $\mathrm{Pu}$ hak but pay directly to the community, please regulate what catches and sells to outside fishermen".

Based on the results of the interview above, it is understood as the fact that the actions of making major changes in Ma'ya civil society in Raja Ampat were architected by organic intellectuals (Gramsci, 2003; Simon, 2004; Bocock, 2011; Lubis, 2016) of the Ma tribe. 'Yes, who were also agents of hegemony to the Ma'ya tribe in Raja Ampat at the time of the establishment of the Raja Ampat conservation area? The organic intellectuals of the Ma'ya tribe in their role in counter-hegemonic actions form traditional intellectual alliances as a support for the counter-hegemonic movement against the Raja Ampat bureaucracy because this traditional intellectual position is closely related to the Ma'ya community and is a channel for communication and interaction with the Ma'ya tribe in Ma'yalibit Bay. Thus

Mentansan, G., Ardhana, P. I. K., Suarka, I. N., \& Dhana, I. N. (2021). Resistance and counter hegemony of Ma'ya tribe to bureaucratic hegemony practices in Raja Ampat, West Papua. International Journal of Linguistics, 
this process does not only require political and economic struggles to create a network of alliances but is a field of ideological struggle to change people's consciousness to build a new view consisting of socialist, economic, and political values, namely being the master of his own country, economically empowered, useful politically.

\subsection{Counter Hegemony through the Stipulation of the Raja Ampat Regent Regulation Number 8 of 2017}

The decline of democracy, the decline in appreciation for the sacrifice of the community from the hard work of handing over their customary water management rights to the Raja Ampat bureaucracy and contributing to caring for and protecting regional conservation areas can be interpreted as a transition towards a moment of higher political rationality among oppressed social layers. The absence of the Raja Ampat bureaucracy on the economic basis of the Teluk Ma'yalibit community was the negligence of the Raja Ampat bureaucracy which resulted in the awakening of the communal consciousness of the Ma'ya tribe. The awakening of the Ma'ya tribe's awareness from the hegemonic power of the bureaucracy has formed a dividing ditch between hegemonic action and the practice of the struggle against the order that has been established in the Raja Ampat bureaucracy.

When these unformed people experience disintegration and are replaced by new social movements/laborers for the conservation of Raja Ampat waters which have a solid social base, these movements can reach a level of maturity that allows them to carry out a long-term struggle against the dominant class, namely the Raja Ampat bureaucracy. This condition in view (Habermas, 2012; Hardiman, 2013) imagines a modern world showing forms of life that have lost the power to encompass and eliminate everything in society, especially in traditional communal societies so that the Raja Ampat bureaucracy has lost its power as due to the depletion of belief and awareness of the Ma'ya tribe which have been rediscovered from the formation of social reality as a conservation community. This situation is confirmed by (Gramsci, 2003) which states that if the ruling class, in this case, the Raja Ampat bureaucracy and its cronies, have lost their consensus, they will use coercive force through the police and military to form a mass coalition in large numbers released from their traditional ideology and coalition. The Ma'ya tribe will no longer trust the Raja Ampat bureaucracy they previously trusted. Based on the understanding of the above theory, it is understood that the ideology and hegemony of the Raja Ampat bureaucracy are dying and have created disappointment and distrust from the Ma'ya community in and around the conservation area. Therefore, when the Raja Ampat bureaucracy loses its trust and consensus it will be dangerous because it has aroused collective awareness to counter-hegemony through the formation of customary fisheries areas that are architected by the organic intellectuals of the Ma'ya tribe.

Violence in the form of monitoring and disciplinary practices that refer to regulative discourses on the social relations of the Ma'ya tribe which was previously considered part of the private domain has been dismantled and directed at the concept of the Ma'ya subculture as the sole ruler. This single ruler is used as a symbol of counterhegemony because the Ma'ya tribe as the original tribe of Raja Ampat must be the main tool and priority in all aspects of life in Raja Ampat. The shift in demarcation lines between the public and the private regarding conservation areas has had a two-sided effect. On the one hand, this shift reveals the political character of social relations and the fact that these social relations are always the result of the modes of the Raja Ampat bureaucratic institutions which give their form and meaning. On the other hand, because Raja Ampat's bureaucratic nature is state intervention, the creation of public spaces for conservation areas for the benefit of fisheries and tourism does not take place in a true form of democratization, but through the act of forcibly applying new forms of trickery power relations, discourse games, and articulations full of political meaning (Agger, 2003). These practices are used as hegemonic practices of conservation NGOs and the Raja Ampat bureaucracy. In the marine conservation area of the Ma'ya tribal area as a plain where several struggles have occurred against the bureaucratic form of state power (Laclau \& Mouffe, 2008) because the emergence of Ma'ya solidarity refers to positive freedom, economic equality, new social rights. , welfare rights become facts of discourse in the motion of the expansion of demands aimed at the Raja Ampat bureaucracy. The demands of the Ma'ya tribe began to be redefined and the liberal-democratic discourse became increasingly modified as a result of the expansion of the realm of rights.

It is based on field research that demands for recognition and legitimacy of rights are fought for and amplified not only by the Raja Ampat bureaucracy but also against the Ma'ya tribe in Ma'ya Bay. This struggle has become a solid foothold and pathway in fighting for the respect of the Ma'ya tribe through the Raja Ampat regent's Regulation Number 8 of 2017 concerning the protection of fish, marine biota, and other potential natural resources in the coastal areas of the sea in the adat Petuanan of the Ma'ya Raja Ampat tribe. The objectives of the regulations promoted and championed by the organic intellectuals of the Ma'ya tribe and their allies, namely: (1) protecting the carrying capacity of marine potential for the long-term welfare of future generations, (2) maintaining marine life, and 
preserving marine potential from irresponsible fishing efforts and activities that damage coral reefs and the natural beauty of the sea, (4) protect indigenous people and their natural marine resources from the use of modern equipment as well as respect, respect, and recognition of people's rights indigenous to the sea and islands, (5) ensuring the availability of food and protein for the indigenous peoples who inhabit the indigenous territories of the Raja Ampat Ma'ya tribes for a long time.

The presence of regent regulation (PERBUP) Number 8 of 2017 which was passed on March 3, 2017, is seen as a counter-hegemonic link flowed by the Ma'ya tribe to the bureaucracy in Raja Ampat Regency, West Papua Province as the hegemony ruler. On another link, there has been a commodification and construction of new hegemony by the Raja Ampat bureaucracy against the Ma'ya tribe which has unwittingly been driven by a regent regulation where it is critically understood that the protection, preservation, development, and empowerment of the Ma'ya community in Ma'ya Bay 'yalibit and the Ma'ya tribe in 4 major islands, namely: Waigeo, Batanta, Salawati, and Misool can be carried out without the Raja Ampat bureaucratic obligation to provide a myriad of managed funds and operational machinery for conservation areas in its waters because the above actions are carried out in a manner custom, selfhelp and voluntary. Kristian Tebu's statement on 10 September 2018 and Abraham Goram Gaman on 11 December 2018 in the digest of a separate interview is stated as follows.

"This customary fishing area was formed so that the community itself can manage it and the benefits will be obtained. But if we want to think critically, this is actually the government's strategy to be willing to bear large costs to manage this large item (conservation area), the government might go bankrupt. So if the community is in this area, the people who are managed by the government need to pay dorang ".

Based on the results of the interview above, it can be concluded that the organic intellectuals of the Ma'ya tribe in Raja Ampat do not realize that through the struggles for the basic rights of the Ma'ya tribe to the management and use of conservation areas, it has contributed to reducing the burden of bureaucratic responsibility in area management. Conservation areas have become the responsibility of the Ma'ya community and it is not the responsibility of the Raja Ampat bureaucracy to contribute to the management and supervision of the area because the Ma'ya tribe has controlled it. Thus the Raja Ampat bureaucracy can reduce the burden of financing to indigenous Ma'ya communities through the establishment of customary fishing areas initiated by the Ma'ya community themselves with the slogan of self-management and self-monitoring.

\section{Conclusion}

The Raja Ampat marine conservation area as a product of the hegemony of the Raja Ampat bureaucracy and international conservation NGOs has for 15 years experienced an anti-climax that creates resistance and counterhegemony as a negative reaction to inhuman hegemonic actions, pruning and freezing of the Ma'ya tribe's space The resistance response resulted in the blocking and closing of monitoring posts for conservation areas in Raja Ampat. Counter-hegemony practices are carried out through the establishment of customary fishing areas and the struggle for the establishment of the Raja Ampat regent's regulation number 8 of 2017 concerning the protection of fish, marine biota, and other potential natural resources in the coastal areas of the sea in the indigenous Ma'ya tribe in Raja Ampat Regency, Papua Province West.

\section{Conflict of interest statement}

The authors declared that they have no competing interests.

\section{Statement of authorship}

The authors have a responsibility for the conception and design of the study. The authors have approved the final article.

\section{Acknowledgments}

First, thanks to the Institution that administers the Domestic Education Fund (Lembaga penyelenggara Dana Pendidikan Dalam Negeri/LPDP-DN) for the scholarship assistance and research funds so that this research can be

Mentansan, G., Ardhana, P. I. K., Suarka, I. N., \& Dhana, I. N. (2021). Resistance and counter hegemony of Ma'ya tribe to bureaucratic hegemony practices in Raja Ampat, West Papua. International Journal of Linguistics, Literature and Culture, 7(3), 120-129. https://doi.org/10.21744/ijllc.v7n3.1476 
completed. Second, thanks to promoters and co-promoters I and II for their directions and guidance in writing articles. 


\section{References}

Agger, B. (2003). Critical Social Theory: Criticism, Applications, and Implications. Yogyakarta: Discourse Creation.

Asaad, I., Lundquist, C. J., Erdmann, M. V., \& Costello, M. J. (2018). Delineating priority areas for marine biodiversity conservation in the Coral Triangle. Biological Conservation, 222, 198-211. https://doi.org/10.1016/j.biocon.2018.03.037

Augustina S., Yuly A., \& Pupuh P. (2015). Basic Data on Social Aspects of Coral Reefs and Related Ecosystems in Raja Ampat Regency. Coremap-CTI. Research Center for Oceanography LIPI.

Bocock, R. (2011). A Comprehensive Introduction to Understanding Hegemony. Yogyakarta: Jalasutra.

Denzin, N. K., \& Lincoln, Y. S. (Eds.). (2011). The Sage handbook of qualitative research. sage.

Ender, A. I., Mangubhai, S., Wilson, J. R., \& Muljadi, A. (2014). Cetaceans in the global centre of marine biodiversity. Marine Biodiversity Records, 7.

Gramsci, A. (2003). Letters from jail . Editions Era.

Grantham, H. S., Agostini, V. N., Wilson, J., Mangubhai, S., Hidayat, N., Muljadi, A., ... \& Possingham, H. P. (2013). A comparison of zoning analyses to inform the planning of a marine protected area network in Raja Ampat, Indonesia. Marine Policy, 38, 184-194. https://doi.org/10.1016/j.marpol.2012.05.035

Habermas, J. (2012). Theory of Communicative Action II Criticism of Rationality. Prints 3. Bantul: Discourse Creation

Hardiman, F. B. (2013). Towards a Communicative Society. Science, Society, Politics and Postmodernism according to Jurgen Habermas. Prints 5. Yogyakarta: Kanisius.

Hedley, G. J., Ward, A. J., Alekseev, A., Howells, C. T., Martins, E. R., Serrano, L. A., ... \& Samuel, I. D. (2013). Determining the optimum morphology in high-performance polymer-fullerene organic photovoltaic cells. Nature communications, 4(1), 1-10.

Laclau, E. \& Mouffe, C. (2008). Hegemony and Socialist Strategy: PostMarxism and New Social Movements. Printing 1. Yogyakarta: Resist Book.

Lubis, A.Y. (2016). Contemporary Critical Thought: From Critical Theory, Cultural Studies, Feminism, Postcolonial, to Multiculturalism. Mold 2. Depok: PT. RajaGrafindo Persada.

Nepomuceno, I., Affonso, H., Fraser, J. A., \& Torres, M. (2019). Counter-conducts and the green grab: Forest peoples' resistance to industrial resource extraction in the Saracá-Taquera National Forest, Brazilian Amazonia. Global Environmental Change, 56, 124-133. https://doi.org/10.1016/j.gloenvcha.2019.04.004

Palomares, M. L. D., Heymans, J. J., \& Pauly, D. (2007). Historical ecology of the Raja Ampat Archipelago, Papua Province, Indonesia. History and philosophy of the life sciences, 33-56.

Patria, N. \& Arif, A. (2003). Antonio Gramsci: State and Hegemony. Yogyakarta: Student Library.

Peters, S., \& Reid, D. K. (2009). Resistance and discursive practice: Promoting advocacy in teacher undergraduate and graduate programmes. Teaching and Teacher Education, 25(4), 551-558. https://doi.org/10.1016/j.tate.2009.02.006

Regent Regulation Number 8 of 2017 Concerning Protection of Fish, Marine Biota and Other Potential Natural Resources in the Deep Sea Coastal Areas of the Ma'ya Raja Ampat Tribe

Sagai, B., Roeroe, K., \& Manembu, I. (2017). Kondisi Terumbu Karang di Pulau Salawati Kabupaten Raja Ampat Papua Barat. Jurnal Pesisir dan Laut Tropis, 5(2), 47-52.

Simon, R. (2004). Gramsci's Political Ideas. Yogyakarta: Student Library.

Sugiyono. (2015). Understanding Qualitative Research. Prints 6. Bandung: Alfabeta.

Varkey, D. A., Ainsworth, C. H., Pitcher, T. J., Goram, Y., \& Sumaila, R. (2010). Illegal, unreported and unregulated fisheries catch in Raja Ampat Regency, Eastern Indonesia. Marine Policy, 34(2), 228-236. https://doi.org/10.1016/j.marpol.2009.06.009

Widayatun, N. F. N. (2016). Peran masyarakat dalam pelestarian terumbu karang dan dampaknya terhadap peningkatan kesejahteraan. Jurnal Kependudukan Indonesia, 6(2), 1-19.

Mentansan, G., Ardhana, P. I. K., Suarka, I. N., \& Dhana, I. N. (2021). Resistance and counter hegemony of Ma'ya tribe to bureaucratic hegemony practices in Raja Ampat, West Papua. International Journal of Linguistics, Literature and Culture, 7(3), 120-129. https://doi.org/10.21744/ijllc.v7n3.1476 